\title{
Priming and growth inhibitor in the production of high-quality pepper seedlings
}

\author{
Abimael Gomes Silva ${ }^{1}$, Flávio Ferreira da Silva Binotti², Adriana Hernandes Pinto Matos ${ }^{3}$, \\ Talita Cristina Campos Pereira da Silva ${ }^{2}$, Tatiane Carla Silva ${ }^{1}$, Edilson Costa ${ }^{2}$ \\ ${ }^{1}$ Universidade Estadual Paulista "Júlio de Mesquita Filho",Faculdade de Engenharia, Ilha Solteira, São Paulo, Brasil. E-mail:
maeldruida@ hotmail.com, tcs.agronomia@gmail.com \\ ${ }^{2}$ Universidade Estadual de Mato Grosso do Sul, Unidade Universitária de Cassilândia, Cassilândia, Mato Grosso do Sul, Brasil. E- \\ mail: binotti@uems.br, talitaagrouems@gmail.com, edilson.costa@uems.br
}

${ }^{3}$ Centro Universitário Una, Unidade de Jataí, Jataí, Goiás, Brasil. E-mail:adriana-hpinto@ @otmail.com

Received: 21/01/2021; Accepted: 08/03/2021.

\begin{abstract}
This study aimed to evaluate the effect of nitrate salts and a growth regulator on seed conditioning. Subsequently, the responses of the influence of the leaf application of paclobutrazol (PBZ) and nitrogen on the quality of seedlings of Capsicum frutescens L. were evaluated. Two experiments were carried out. The first experiment was conducted in a completely randomized design to evaluate priming, as follows: T1 - control, T2 - control (water), $\mathrm{T} 3-0.2 \%$ calcium nitrate, $\mathrm{T} 4-0.2 \%$ potassium nitrate, $\mathrm{T} 5-0.1 \%$ calcium nitrate $+0.1 \%$ potassium nitrate, $\mathrm{T} 6-$ $\mathrm{PBZ}$, and $\mathrm{T} 7-\mathrm{PBZ}+0.1 \%$ calcium nitrate $+0.1 \%$ potassium nitrate. The second experiment was carried out in a completely randomized design in a $2 \times 5$ factorial scheme consisting of priming (absence and presence of calcium nitrate) and leaf application of growth regulator, as follows: control (water), PBZ, PBZ + $1 \%$ nitrogen (calcium nitrate), PBZ $+1 \%$ nitrogen (urea), and PBZ + nitrogen $(0.5 \%$ calcium nitrate $+0.5 \%$ urea). Physiological conditioning with a solution of $0.1 \%$ calcium nitrate increased the germination and seedling emergence rate and resulted in seedlings with a higher shoot length at 33 days after sowing (DAS), but seedlings at 50 DAS showed no differences in growth with its use. Leaf application of $0.1 \%$ paclobutrazol provided pepper (C. frutescens L.) seedlings with better distribution in growth according to the Dickson quality index.
\end{abstract}

Keywords: Capsicum frutescens L., potassium nitrate, calcium nitrate, seedling quality.

\section{Priming e inibidor de crescimento na produção de mudas de pimenteiras de elevada qualidade}

\section{RESUMO}

Objetivou-se avaliar o efeito de sais de nitrato e regulador de crescimento no condicionamento de sementes. Posteriormente avaliou-se as respostas da influência da aplicação foliar do paclobutrazol (PBZ) e o nitrogênio na qualidade de mudas de Capsicum frutesces L. Foram realizados dois experimentos: o primeiro, com delineamento inteiramente casualizado (DIC) avaliando priming, sendo eles: T1:testemunha; T2:controle - água; T3: nitrato de cálcio $0,2 \%$; T4: nitrato de potássio $0,2 \%$; T5: nitrato de cálcio $0,1 \%$ + nitrato de potássio 0,1\%; T6: PBZ, T7: PBZ + nitrato de cálcio $0,1 \%$ + nitrato de potássio $0,1 \%$. O segundo experimento, em DIC, em esquema fatorial 2 X 5 constituído de priming (ausência e presença de nitrato de cálcio) e aplicação foliar de regulador de crescimento: testemunha (aplicação de água), PBZ, PBZ + nitrogênio 1\% (nitrato de cálcio), PBZ + nitrogênio 1\% (ureia) e PBZ + nitrogênio (nitrato de cálcio $0,5 \%$ + ureia $0,5 \%$ ). O condicionamento fisiológico com solução de $0,1 \%$ de nitrato de cálcio aumentou a velocidade de germinação e emergência de plântulas e resultou em mudas com maior comprimento da parte área aos 33 DAS, todavia em mudas aos 50 DAS não apresentou diferenças de crescimento com seu uso. A aplicação foliar de 0,1\% paclobutrazol proporcionou, de acordo com os valores de IQD, mudas de pimenteira (Capsicum frutescens L.) com melhor distribuição no crescimento.

Palavras-chave: Capsicum frutescens L., nitrato de potássio, nitrato de cálcio, qualidade de mudas.. 


\section{Introduction}

Peppers (Capsicum frutescens L.) are vegetables that produce spicy fruits, and their seedlings are obtained by sowing. The incorporation of chemical agents in the method of physiological conditioning of seeds (priming) is a way to guarantee vigorous seedlings (Kerbauy, 2013; Caixeta et al., 2014; Batista et al., 2015; Marcos Filho, 2015; Silva et al., 2017). Nitric oxide, which is obtained using salts such as calcium nitrate and potassium nitrate, can be used to favor plant development and growth (Sanz et al., 2015; Salles et al., 2019). The effects of nitrate are related to several pathways in the initial germination processes and even in overcoming seed dormancy (Brasil, 2009; Kerbauy, 2013; Cardoso et al, 2015; Sanz et al., 2015). The incorporation of these salts can accelerate the germination rate (Binotti et al., 2014), a higher initial seedling growth (Batista et al., 2015), and increase the tolerance to abiotic stresses (Batista et al., 2016, Gouveia et al., 2017).

Seedling quality can also be altered by manipulating plant architecture using growth regulators or inhibitors, and plant growth must maintain adequate proportions (Benett et al., 2014; Binotti et al., 2019; Matos et al., 2020). Seedlings that present the shoot very developed in comparison with the root system are considered fragile and may present a high mortality rate in the field.

Some growth inhibitors, such as paclobutrazol (PBZ), act inhibiting gibberellin production, a hormone responsible for vegetative growth and used to avoid etiolation, lodging, or even the competition between plants (Brito et al., 2016; Pacentchuk et al., 2018). These substances can be used directly in the soil/substrate in the treatment of seeds or sprayed on the leaf surface (Benett et al., 2014; Parladore et al., 2019; Ascoli et al., 2020; Matos et al., 2020). Plants with a lower shoot height, but with a well-developed root system, an important characteristic for plant survival in the face of water stress, can be obtained depending on how it is applied (Wanderley et al., 2014, Binotti et al., 2019).

Given these assumptions, this study aimed to evaluate the effect of nitrate salts and PBZ growth regulator on seed priming and the influence of the leaf application of PBZ and nitrogen on the quality seedlings of $C$. frutescens $\mathrm{L}$.

\section{Material and Methods}

Two experiments were carried out using pepper $(C$. frutescens L.) seeds without previous treatment, whose initial quality was determined before the experiment set up, with an average germination rate of $90 \%$. Salts (calcium nitrate and potassium nitrate) and the growth inhibitor paclobutrazol (PBZ) were used in the solutions used as treatments. The solutions were prepared using deionized water.

First experiment: The experimental design was completely randomized with four replications and seven solutions used in the physiological conditioning (priming) of the seeds, as follows: T1 - control (no conditioning), T2 - control (conditioned with water), $\mathrm{T} 3-0.2 \%$ calcium nitrate $\left(\mathrm{Ca}\left(\mathrm{NO}_{3}\right)_{2}\right), \mathrm{T} 4-0.2 \%$ potassium nitrate $\left(\mathrm{KNO}_{3}\right), \mathrm{T} 5-0.1 \%$ calcium nitrate + $0.1 \%$ potassium nitrate, T6 $-0.1 \% \mathrm{PBZ}$, and $\mathrm{T} 7-0.1 \%$ $\mathrm{PBZ}+0.1 \%$ calcium nitrate $+0.1 \%$ potassium nitrate

The hydration method between germitest paper sheets was used for seed conditioning (Alves et al., 2015, Batista et al., 2015). After the treatments, the seeds dried at room temperature were stored in paper packages for three days and later used to conduct the experiments. The following tests and respective variables were considered to verify the effect of the treatments:

I - Germination tests (laboratory test): carried out under ideal conditions, according to Brasil (2009). Percentage of germination (PG): performed with four subsamples of 50 seeds each, uniformly distributed in plastic gerbox boxes and blotting paper as a substrate for water supply. This procedure was evaluated 14 days after the test was set up (Brasil, 2009). Germination rate index (GRI): performed simultaneously with the count of the percentage of germination with daily evaluations and using a modified equation from Maguire (1962): GRI = $\Sigma(\mathrm{Ni} / \mathrm{Di})$, where $\mathrm{Ni}$ is the number of germinated seeds on the day i, Di represents the days after sowing in which there was germination up to the stability of the number of germinated seeds, and i represents the 1 st $\rightarrow 14$ th day.

II - Electrical conductivity test (laboratory test): the mass of four sub-samples of 50 seeds was measured and later placed to soak in containers with a volume of $75 \mathrm{~mL}$ of deionized water and then maintained in a chamber (germinator) at a temperature of $25{ }^{\circ} \mathrm{C}$ for 24 hours. After this period, the electrical conductivity in the soaking solution was read using a conductivity meter. The results were expressed in $\mu \mathrm{S}$ $\mathrm{cm}^{-1} \mathrm{~g}^{-1}$ of seeds.

The cultivation tray used in the tests was made of polystyrene with 128 cells and the substrate was formulated with bovine manure, soil from a hillside, and vermiculite with medium particle size $(1: 1: 1$ $\mathrm{v} / \mathrm{v} / \mathrm{v})$. The soil used as substrates for seedling production was analyzed (Table 1 ). 
Table 1. Chemical characteristics of hillside soil. Cassilândia, MS, Brazil, 2016.

\begin{tabular}{cccccccc}
\hline $\mathrm{pH}$ & \multicolumn{2}{c}{$-------\mathrm{cmol} \mathrm{dm}^{-3}-------$} & & $\mathrm{mg} \mathrm{dm}^{-3}$ & $\mathrm{cmolc}$ & \multicolumn{2}{c}{$\mathrm{g} \mathrm{dm}^{-3}$} \\
\hline $\mathrm{CaCl}_{2}$ & $\mathrm{Ca}$ & $\mathrm{Mg}$ & $\mathrm{Al}$ & $\mathrm{P}(\mathrm{Mel})$ & $\mathrm{CEC}$ & $\mathrm{OM}$ & $\mathrm{OC}$ \\
5.8 & 244 & 8.8 & 3.3 & 1,8 & 12.5 & 35,6 & 13.9 \\
\hline \multicolumn{2}{c}{$\mathrm{mg} \mathrm{dm}^{-3}(\mathrm{ppm})$} & & $-------\mathrm{mg} \mathrm{dm}^{-3}(\mathrm{ppm})$. Mehlich $^{-1}--------$ & & $\%$ \\
\hline $\mathrm{S}$ & $\mathrm{B}$ & $\mathrm{Cu}$ & $\mathrm{Fe}$ & $\mathrm{Mn}$ & $\mathrm{Zn}$ & $\mathrm{Na}$ & $\mathrm{BS}$ \\
4.8 & 0.13 & 0,4 & 14 & 90,5 & 1.7 & $\mathrm{~ns}$ & 44,9 \\
\hline
\end{tabular}

$\mathrm{OM}=$ organic matter; $\mathrm{OC}=$ organic carbon; $\mathrm{BS}=$ base saturation

III - Emergence test (greenhouse test): a commercial substrate and multi-cell cultivation trays were used. Each treatment consisted of four replicates of 50 seeds maintained under cultivation with $50 \%$ shading. The percentage of emergence (PE) was evaluated at 33 days after sowing (DAS). Emergence rate index (ERI): performed with daily counting and using a modified equation from Maguire (1962), that is, $\mathrm{ERI}=\Sigma(\mathrm{Ni} / \mathrm{Di})$, where $\mathrm{Ni}$ is the number of seedlings that emerged on the day i, and Di represents the days after sowing in which the emergence occurred up to the stability of the emerged seedlings, and i represents the $1 \rightarrow 33$ rd day. Height and dry phytomass: seedlings obtained from the previous evaluation were used for this analysis.

Second experiment: IV - Test of seedling growth and quality under the effect of priming and leaf application of solutions. The experiment was set up in a completely randomized design in a $2 \times 5$ factorial arrangement consisting of physiological conditioning of seeds (absence and presence of calcium nitrate) and leaf application of different chemical agents on the seedlings, as follows: T1 - control (water application), $\mathrm{T} 2-0.1 \%$ paclobutrazol (PBZ), T3 $-0.1 \% \mathrm{PBZ}+1 \%$ nitrogen (calcium nitrate), $\mathrm{T} 4-0.1 \% \mathrm{PBZ}+1 \%$ nitrogen (urea), and T5 - 0.1\% PBZ + nitrogen $(0.5 \%$ calcium nitrate $+0.5 \%$ urea), with 8 replications.

The shoot height of seedlings (SH) and stem diameter (SD) were used to evaluate the second experiment. These variables were obtained using a millimeter ruler and a digital caliper, respectively. Root dry mass (RDM), shoot dry mass (SDM), and total dry mass (TDM) were also evaluated. For this, the seedlings were taken from the substrate, washed in running water, and the root system was separated from the shoot. The parts were placed in paper bags with known mass and placed in a forced-air circulation oven at $80{ }^{\circ} \mathrm{C}$ for 24 hours. Subsequently, the masses were measured, and the results expressed in $\mathrm{mg}$ seedling ${ }^{-1}$ (adapted from Nakagawa, 1999). The SDM/RDM ratio and the Dickson quality index were calculated using the equation DQI $=\mathrm{TDM} /(\mathrm{SH} / \mathrm{SD}+\mathrm{SDM} / \mathrm{RDM})($ Dickson et al., 1960).

All data were evaluated through analysis of variance by the F-test and the Tukey test of comparison of means was applied if significance was found between treatments (Banzatto and Kronka, 2006). The software SISVAR v. 5.6 was used in the statistical analysis (Ferreira, 2014; Ferreira, 2019).

\section{Results and Discussion}

In the first experiment, in the germination tests, the physiological conditioning (priming) as paclobutrazol did not allow seed germination and, consequently, seedling growth under the dose of $0.1 \%$ PBZ (Table $2)$. Thus, these results were not included in the statistical analysis. Melo et al. (2014) found a similar result in an experiment with tomato seeds, concluding that the use of this growth inhibitor directly on the seed impairs germination and vigor. It may have occurred because this substance affects the degradation of reserve tissues and gibberellin biosynthesis, thus blocking important metabolic pathways for resuming the growth of the embryonic axis (Lenton et al., 1994).

Seed conditioning provided an increase in the percentage of germination at the first count, but it did not influence the number of seeds to complete germination at the end of the process (total germination). Physiological conditioning with nitrate, $\mathrm{KNO} 3$, or $\mathrm{Ca}(\mathrm{NO} 3) 2$ salts alone resulted in the highest GRI in comparison with the germination resulting from the control. Hypocotyl length and the total dry mass of seedlings were not influenced by the treatments, but seeds that passed through the physiological conditioning process in the accelerated aging test showed a lower percentage of germination than the control (Table 3).

The physiological conditioning was not enough to maintain seed germination under stress conditions, as observed in the aging test (Table 2). Several factors are involved for its effectiveness, such as the initial physiological potential of the lot (vigor) and persistence of priming during seed storage. Accelerated aging is a test with high sensitivity for efficiently determining seed vigor (Marcos Filho, 2015). According to Brandão and Lopes (2019), this test can generate inaccurate results in small-sized seeds, as in the case of pepper seeds. 
Table 2. Germination tests: first germination count (FGC), total germination (TG), germination rate index (GRI), percentage of germination after accelerated aging (AA), hypocotyl length (HL), and total dry mass (TDM) of seedlings as a function of the chemical agents used in the physiological conditioning of Capsicum frutescens seeds. Cassilândia, MS, Brazil, 2016.

\begin{tabular}{llll}
\hline Seed treatment & FGC $(\%)$ & TG $(\%)$ & GRI \\
\hline Control & $3 \mathrm{~b}$ & $90 \mathrm{a}$ & $4.68 \mathrm{~b}$ \\
$\mathrm{Control}$ (water) & $31 \mathrm{a}$ & $84 \mathrm{a}$ & $5.33 \mathrm{ab}$ \\
$\mathrm{KNO}_{3}$ & $41 \mathrm{a}$ & $91 \mathrm{a}$ & $5.95 \mathrm{a}$ \\
$\mathrm{Ca}\left(\mathrm{NO}_{3}\right)_{2}$ & $47 \mathrm{a}$ & $88 \mathrm{a}$ & $5.95 \mathrm{a}$ \\
$\mathrm{KNO}_{3}+\mathrm{Ca}\left(\mathrm{NO}_{3}\right)_{2}$ & $48 \mathrm{a}$ & $81 \mathrm{a}$ & $5.55 \mathrm{ab}$ \\
$\mathrm{PBZ}+$ nutrient & - & - & - \\
$\mathrm{PBZ}$ & - & - & - \\
\hline $\mathrm{CV}(\%)$ & 12.79 & 6.48 & 8.72 \\
\hline $\mathrm{Seed} \mathrm{treatment}$ & $\mathrm{AA}(\%)$ & $\mathrm{HL}(\mathrm{cm})$ & TDM (mg seedling $\left.{ }^{-1}\right)$ \\
\hline $\mathrm{Control}$ & $88 \mathrm{a}$ & $1.42 \mathrm{a}$ & $0.0168 \mathrm{a}$ \\
$\mathrm{Control}($ water $)$ & $49 \mathrm{~b}$ & $1.37 \mathrm{a}$ & $0.0210 \mathrm{a}$ \\
$\mathrm{KNO}$ & $54 \mathrm{~b}$ & $1.41 \mathrm{a}$ & $0.0201 \mathrm{a}$ \\
$\mathrm{Ca}\left(\mathrm{NO}_{3}\right)_{2}$ & $56 \mathrm{~b}$ & $1.35 \mathrm{a}$ & $0.0176 \mathrm{a}$ \\
$\mathrm{KNO}$ & $\mathrm{Ca}\left(\mathrm{NO}_{3}\right)_{2}$ & $1.52 \mathrm{a}$ & $0.0202 \mathrm{a}$ \\
$\mathrm{PBZ}+$ nutrient & $53 \mathrm{~b}$ & - & - \\
$\mathrm{PBZ}$ & - & - & - \\
\hline $\mathrm{CV}(\%)$ & - & 9.48 & 12.16 \\
\hline
\end{tabular}

Control: without physiological conditioning; $\mathrm{KNO}_{3}$ : potassium nitrate; $\mathrm{Ca}\left(\mathrm{NO}_{3}\right)_{2}$ : calcium nitrate. Means followed by different letters in the columns differ statistically from each other by the Tukey test at $5 \%$ probability.

Table 3. Emergence tests: Seedling height at emergence (SHE), total emergence (TE), and emergence rate index (ERI) as a function of the chemical agents used in the physiological conditioning of Capsicum frutescens seeds. Cassilândia, MS, Brazil, 2016.

\begin{tabular}{llll}
\hline Treatment & SHE $(\mathrm{cm})$ & TE $(\%)$ & ERI \\
\hline Control & $1.18 \mathrm{~b}$ & $78 \mathrm{a}$ & $3.84 \mathrm{~b}$ \\
$\mathrm{Control}$ (water) & $1.19 \mathrm{~b}$ & $85 \mathrm{a}$ & $4.87 \mathrm{ab}$ \\
$\mathrm{KNO}_{3}$ & $1.23 \mathrm{ab}$ & $85 \mathrm{a}$ & $5.19 \mathrm{a}$ \\
$\mathrm{Ca}\left(\mathrm{NO}_{3}\right)_{2}$ & $1.28 \mathrm{a}$ & $81 \mathrm{a}$ & $4.95 \mathrm{a}$ \\
$\mathrm{KNO}_{3}+\mathrm{Ca}\left(\mathrm{NO}_{3}\right)_{2}$ & $1.17 \mathrm{~b}$ & $88 \mathrm{a}$ & $4.71 \mathrm{ab}$ \\
$\mathrm{PBZ}+$ nutrient & - & - & - \\
$\mathrm{PBZ}$ & - & - & - \\
\hline $\mathrm{CV}(\%)$ & 3.25 & 9.2 & 10.18
\end{tabular}

Control: without physiological conditioning; $\mathrm{KNO}_{3}$ : potassium nitrate; $\mathrm{Ca}\left(\mathrm{NO}_{3}\right)_{2}$ : calcium nitrate. Means followed by different letters in the columns differ statistically from each other by the Tukey test at $5 \%$ probability.

The physiological conditioning was not enough to maintain seed germination under stress conditions, as observed in the aging test (Table 2). Several factors are involved for its effectiveness, such as the initial physiological potential of the lot (vigor) and persistence of priming during seed storage. Accelerated aging is a test with high sensitivity for efficiently determining seed vigor (Marcos Filho, 2015).

According to Brandão and Lopes (2019), this test can generate inaccurate results in small-sized seeds, as in the case of pepper seeds. The beneficial effect of seed conditioning may not persist over the seed storage period (Batista et al., 2020; Silva and Marcos-Filho, 2020). According to Marcos Filho (2015), the process has several advantages, as the physiological conditioning guarantees the absorption of water under controlled conditions, allowing the beginning of the germination process, activating phases I and II of germination, but not the phase of radicle protrusion. This process results in metabolically uniform seeds and this uniformity was demonstrated in the first germination count.

Emergence and electrical conductivity: Seedling height and emergence rate index (ERI) were influenced by treatments. Seedlings with higher height were the result of the use of calcium nitrate compared to the controls. Both calcium nitrate and potassium nitrate similarly promoted higher ERI than the control treatment. The total emergence (Table 3 ) and the total seedling dry mass (Table 4) were not influenced by the different treatments used in seed conditioning.

The electrical conductivity test allows the evaluation of the deterioration process according to the amount of 
leaked components from the seed cells soaked in water. The more compromised the integrity of the cell membrane systems, the higher the quantity of leaked components, resulting in a higher electrical conductivity (Vieira and Krzyzanowski, 1999; Marcos Filho, 2015).

Therefore, all treatments were equal regarding the release of exudates in the soaking solution, except for those submitted to the treatment consisting only of PBZ solution (Table 4), as this product probably inhibits the biosynthesis of amylases because it inhibits gibberellin, which are involved in the degradation of the reserve tissue into soluble compounds. Thus, less degradation would lead to a lower amount to be lost by the seeds in the exudate of the soaking solution.

These initial tests served to choose which of the solutions would be more appropriate for the physiological conditioning of seeds of this species, and the second experiment aimed to demonstrate whether the effects of the seed treatment last until the phase of collecting the pepper seedlings at 50 DAS. The initial results demonstrate similarities in the effect of both calcium nitrate and potassium nitrate on seed conditioning for seedlings at 33 DAS. According to Salles et al. (2019), the priming of eggplant seeds with calcium nitrate resulted in the highest germination rate of seeds and seedlings with the highest radicle emission rate. Calcium nitrate and potassium nitrate are salts that can release nitric oxide (NO), which are required in several physiological processes related to plant growth and development and provide resistance to abiotic stresses and resistance to pathogens (Sanz et al., 2015).

Nitrate undergoes reduction and changes to the nitrite form, causing the reoxidation of $\mathrm{NAD}(\mathrm{P}) \mathrm{H}$, later making $\mathrm{NAD}(\mathrm{P})$ available, which will act by stimulating the pentose phosphate pathway and, consequently, the shikimic acid pathway through the erythrose-4-phosphate. These two pathways are essential for the biosynthesis of new compounds.

No statistical difference was observed between treatments for the variables shoot height $(\mathrm{SH})$, root system length (RL), and stem diameter (SD). PBZ can be more efficient when it enters plant systems through the root than through the leaves, varying its response according to the used dose (Table 5).

Table 4. Total seedling dry mass (TDM) during emergence and electrical conductivity test (EC) as a function of the chemical agents used in the physiological conditioning of Capsicum frutescens seeds. Cassilândia, MS, Brazil, 2016.

\begin{tabular}{lll}
\hline Treatment & TDM $(\mathrm{mg})$ & EC $\left(\mu \mathrm{Sm}^{-1} \mathrm{~g}^{-1}\right)$ \\
\hline Control & $0.0933 \mathrm{a}$ & $31.79 \mathrm{a}$ \\
Control (water) & $0.1001 \mathrm{a}$ & $17.02 \mathrm{ab}$ \\
$\mathrm{KNO}_{3}$ & $0.0996 \mathrm{a}$ & $30.88 \mathrm{a}$ \\
$\mathrm{Ca}\left(\mathrm{NO}_{3}\right)_{2}$ & $0.1045 \mathrm{a}$ & $31.71 \mathrm{a}$ \\
$\mathrm{KNO}_{3}+\mathrm{Ca}\left(\mathrm{NO}_{3}\right)_{2}$ & $0.1022 \mathrm{a}$ & $22.74 \mathrm{ab}$ \\
$\mathrm{PBZ}+$ nutrient & - & $17.65 \mathrm{ab}$ \\
$\mathrm{PBZ}$ & - & $11.61 \mathrm{~b}$ \\
\hline C.V $(\%)$ & 7.13 & 19.98 \\
\hline
\end{tabular}

Control: without physiological conditioning; KNO3: potassium nitrate; $\mathrm{Ca}(\mathrm{NO} 3) 2$ : calcium nitrate. Means followed by different letters in the columns differ statistically from each other by the Tukey test at $5 \%$ probability.

Table 5. Shoot height (SH), root system length (RL), and stem diameter (SD) as a function of the physiological conditioning of seeds and leaf application of chemical agents on Capsicum frutescens. Cassilândia, MS, Brazil, 2016.

\begin{tabular}{llll}
\hline Treatment & SH $(\mathrm{cm})$ & RL $(\mathrm{cm})$ & SD $(\mathrm{cm})$ \\
\hline Physiological conditioning & & & $1.433 \mathrm{a}$ \\
Presence & $0.588 \mathrm{a}$ & $0.210 \mathrm{a}$ & $1.377 \mathrm{a}$ \\
Absence & $0.552 \mathrm{a}$ & $0.205 \mathrm{a}$ & $1.459 \mathrm{a}$ \\
Leaf application & & & $1.398 \mathrm{a}$ \\
Control & $0.653 \mathrm{a}$ & $0.181 \mathrm{a}$ & $1.383 \mathrm{a}$ \\
PBZ & $0.552 \mathrm{a}$ & $0.220 \mathrm{a}$ & $1.359 \mathrm{a}$ \\
PBZ + calcium nitrate & $0.533 \mathrm{a}$ & $0.194 \mathrm{a}$ & $1.424 \mathrm{a}$ \\
PBZ + urea & $0.524 \mathrm{a}$ & $0.215 \mathrm{a}$ & 6.5 \\
PBZ + calcium nitrate + urea & $0.590 \mathrm{a}$ & $0.218 \mathrm{a}$ & 15.5 \\
\hline CV $(\%)$ & 19.2 & $\mathrm{~T}$ & $\mathrm{~T}$ \\
\hline
\end{tabular}

Control: leaf application of water. Means followed by the same letter in the column are not different by the Tukey test at $5 \%$ probability for the leaf application factor and the F-test for the physiological treatment. 
The pentose phosphate pathway synthesizes the ribulose-5-phosphate, used in the synthesis of nucleotides, which are constituents of nucleic acids (RNA and DNA) and synthesis of coenzymes, which may influence the germination process. The shikimic acid pathway is essential for the biosynthesis of essential amino acids, such as tryptophan, phenylalanine, and tyrosine, phenolic compounds, and other secondary compounds (Cardoso et al, 2015).

In the second experiment: growth and quality of seedlings under the effect of seed treatment and leaf application of solutions, the factorial arrangement of seed treatments and leaf application was not significant ( $\mathrm{p}$-value > 0.05) and, therefore, the influence of each factor was analyzed alone in the pepper seedlings.

Shoot, root, and total dry masses were not influenced by treatments (Table 6). However, the shoot to root dry mass ratio (DMR) between treatments with solutions in which $\mathrm{PBZ}$ is present provided lower DMR (Table 7).

Parladore et al (2019) observed the influence of PBZ application on growth variables of the cultivar Pirâmide, at 60 DAS, not changing the quality indices. Thus, the results of the interaction between the PBZ solution with the species/cultivar and application method can be different. The effect of the inhibitor ceases as soon as its molecules are no longer found in the plant architecture, thus normalizing plant growth.

Therefore, further studies with the use of this inhibitor are suggested to assess, for example, the effect of multiple applications or association of PBZ with other substances, in addition to studies that seek to demonstrate its ideal dose for understanding the effect of this inhibitor on the production of vegetable seedlings.

Table 6. Shoot dry mass (SDM), root dry mass (RDM), and total dry mass (TDM) as a function of the physiological conditioning of seeds and leaf application of chemical agents on Capsicum frutescens. Cassilândia, MS, Brazil, 2016.

\begin{tabular}{llll}
\hline Treatment & SDM & RDM & TDM \\
\hline Physiological conditioning & & & $0.066 \mathrm{a}$ \\
Presence & $0.040 \mathrm{a}$ & $0.017 \mathrm{a}$ & $0.063 \mathrm{a}$ \\
Absence & $0.040 \mathrm{a}$ & $0.017 \mathrm{a}$ & $0.069 \mathrm{a}$ \\
Leaf application & & & $0.064 \mathrm{a}$ \\
Control & $0.055 \mathrm{a}$ & $0.015 \mathrm{a}$ & $0.061 \mathrm{a}$ \\
PBZ & $0.046 \mathrm{a}$ & $0.018 \mathrm{a}$ & $0.061 \mathrm{a}$ \\
PBZ + calcium nitrate & $0.044 \mathrm{a}$ & $0.016 \mathrm{a}$ & $0.067 \mathrm{a}$ \\
PBZ + urea & $0.044 \mathrm{a}$ & $0.018 \mathrm{a}$ & 17.6 \\
PBZ + calcium nitrate + urea & $0.049 \mathrm{a}$ & $0.018 \mathrm{a}$ & 15.5 \\
\hline CV $(\%)$ & 19.3 & & ar
\end{tabular}

Control: leaf application of water. Means followed by the same letter in the column are equal by the Tukey test at 5\% probability for the leaf application factor and the F-test for the physiological treatment.

Table 7. Shoot to root dry mass ratio (DMR) and Dickson quality index (DQI) as a function of the physiological conditioning of seed and leaf application of chemical agents on Capsicum frutescens. Cassilândia, MS, Brazil, 2016.

\begin{tabular}{lll}
\hline Treatment & DMR & DQI \\
\hline Physiological conditioning & & \\
Presence & $2.879 \mathrm{a}$ & $0.020 \mathrm{a}$ \\
Absence & $2.729 \mathrm{a}$ & $0.021 \mathrm{a}$ \\
Leaf application & & \\
Control & $3.629 \mathrm{a}$ & $0.017 \mathrm{~b}$ \\
PBZ & $2.517 \mathrm{~b}$ & $0.022 \mathrm{a}$ \\
PBZ + calcium nitrate & $2.740 \mathrm{~b}$ & $0.020 \mathrm{ab}$ \\
PBZ + urea & $2.427 \mathrm{~b}$ & $0.022 \mathrm{a}$ \\
PBZ + calcium nitrate + urea & $2.706 \mathrm{~b}$ & $0.021 \mathrm{a}$ \\
\hline CV $(\%)$ & 10.8 & 17.6
\end{tabular}

Control: leaf application of water. Means followed by the same letter in the column are equal by the Tukey test at 5\% probability for the leaf application factor and the F-test for the physiological treatment. 


\section{Conclusions}

The effects of physiological conditioning of seeds with a $0.1 \%$ calcium nitrate solution increased the germination and emergence rate of seedlings, resulting in their higher shoot length at 33 DAS. However, seedlings at 50 DAS showed no differences in growth with its use. The leaf application of $0.1 \%$ paclobutrazol provided, according to the DQI values, pepper $(C$. frutescens L.) seedlings with better distribution in growth.

\section{Authors' Contribution}

Abimael Gomes da Silva was responsible for the implementation of the experiments, data collection, statistical analysis, and writing of the manuscript. Flávio Ferreira da Silva Binotti elaborated the initial project, submitted it for a scholarship request, and guided the experiment set up, data collection, writing, and revisions of the manuscript. Adriana Hernandes Pinto Matos and Talita Cristina Campos Pereira da Silva assisted in setting up the experiments and collecting data and revising the manuscript. Tatiane Carla Silva participated in the revisions of the manuscript. Edilson Costa guided the experiment set up, data collection, writing and revisions of the manuscript.

\section{Acknowledgments}

To the Fundação de Apoio ao Desenvolvimento de Ensino, Ciência e Tecnologia do Estado de Mato Grosso do Sul (FUNDECT) for financial support (FUNDECT/CNPq/UEMS No. 01/2015 - PIBIC-UEMS and UNIVERSAL-MS, FUNDECT 165/2014).

\section{Bibliographic References}

Alves, C.Z., Silva, J.B., Cândido, A.C.S. 2015. Methodology for carrying out the germination test in guava seeds. Revista Ciência Agronômica, 46 (3), 615-621. DOI: https://doi.org/10.5935/1806-6690.20150045

Ascoli, A.A., Binotti, F.F.S., Mendonça, G.W., Gouveia, G.C.C., Costa, E., Cardoso, E.D. 2020. Effects of foliar application of chemical agents and shading levels on growth and physiological aspects of "malagueta" pepper plants. Australian Journal of Crop Science, 14(02), 229-235. DOI: https://doi.org/10.21475/ajcs.20.14.02.p1852

Banzatto, D.A., Kronka, S.N. 2006. Experimentação Agrícola. Funep, Jaboticabal.

Batista, T.B., Binotti, F.F.S., Cardoso, E.D., Bardiviesso, E.M., Costa, E. 2015. Aspectos fisiológicos e qualidade de mudas da pimenteira em resposta ao vigor e condicionamento das sementes. Bragantia, 74(1), 367-373. DOI: https://doi.org/10.1590/1678-4499.0133
Batista, T.B., Cardoso, E.D., Binotti, F.F.S., Costa, E., Sá, M.E. 2016. Priming and stress under high humidity and temperature on the physiological quality of Brachiaria brizantha cv. MG-5 seeds. Acta Scientarum, 38(4), 123-127. DOI: https://doi.org/10.4025/actasciagron.v38i1.26021

Batista, T.B.; Fernandez, J.J.; Silva, T.A.; Maia, J.; Silva, E.A.A. 2020. Transcriptome analysis in osmo-primed tomato seeds with enhanced longevity by heat shock treatment. AoB

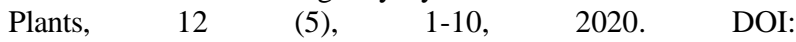
https://doi.org/10.1093/aobpla/plaa041

Benett, K.S.S., Faria Junior, M.J.A., Benett, C.G.S., Seleguini, A., Lemos, O.L. 2014. Utilização de paclobutrazol na produção de mudas de tomateiro. Comunicata Sscientia, 5(2), 164-169.DOI: https://doi.org/10.14295/cs.v5i2.295

Binotti, E.D.C., Costa, E., Binotti, F.F.S., Batista, B.T. 2019. Chemical agents and shading levels for the production of pepper seedlings. Engenharia Agrícola, 38(4), 450-456. DOI: https://doi.org/10.1590/1809-4430-Eng.Agric.v38n4p450$456 / 2018$

Binotti, F.F.S., Sueda Junior, C.I., Cardoso, E.D., Haga, K.I., Nogueira, D.N. 2014. Tratamentos pré-germinativos em sementes de Brachiaria. Agrária, 9(4), 614-618. DOI: https://doi.org/10.5039/agraria.v9i4a2781

Brandão, A.A., Lopes, H.M. 2019. Envelhecimento acelerado de sementes de alface produzidas no manejo orgânico em cultivo protegido e a céu aberto. Revista Agrogeoambiental, 10(4). DOI: https://doi.org/10.18406/2316$1817 \mathrm{v} 10 \mathrm{n} 420181136$

BRASIL. Ministério da Agricultura, Pecuária e Abastecimento/Secretaria de Defesa Agropecuária. 2009. Regras para análise de sementes. Mapa/ACS, Brasília.

Brito, C.L.L., Matsumo, S.N., Santos, J.L., Gonçalves, D.N., Ribeiro, A.F.F. 2016. Efeito do paclobutrazol no desenvolvimento de plantas de girassol ornamental. Revista de Ciências Agrárias, 39(1), 153-160. DOI: https://doi.org/10.19084/RCA15044

Caixeta, F., Von Pinho, E.V.R., Guimarães, R.M., Pereira, P.H.A.R., Catão, H.C.R.M., Clemente, A.C.S. 2014. Determinação do ponto de colheita na produção de sementes de pimenta malagueta e alterações bioquímicas durante o armazenamento e a germinação. Científica, 42(2), 187-197. DOI: http://dx.doi.org/10.15361/1984-5529.2014v42n2p187197

Cardoso, E.D.; Sá, M.E.; Haga, K.I.; Binotti, F.F.S.; Costa, E. 2015. Qualidade fisiológica e composição química de sementes de Brachiaria brizantha em função do condicionamento osmótico. Revista de Agricultura Neotropical, 2 (2), 42-48. DOI: https://doi.org/10.32404/rean.v2i2.264

Dickson, A., Leaf, A.L., Hosner, J.F. 1960. Quality appraisal of white spruce and white pine seedling stock in nurseries. Forestrychronicle, 36(1), $0-13$. https://doi.org/10.5558/tfc36010-1

Ferreira, D. F. 2014. SISVAR: a guide for its Bootstrap procedures in multiple comparisons. Ciência e Agrotecnologia. $\quad 38(2), \quad 109-112 . \quad$ DOI: https://doi.org/10.1590/S1413-70542014000200001 
Ferreira, D.F. 2019. SISVAR: a computer analysis system to fixed effects split plot type designs. Revista Brasileira de Biometria, 37(4), 529-535. DOI: https://doi.org/10.28951/rbb.v37i4.450

Gouveia, G.C.C.; Binotti, F.F.S.; Costa, E. 2017. Priming effect on the physiological potential of maize seeds under abiotic stress. Pesquisa Agropecuaria Tropical, 47 (3), 328335. DOI: http://dx.doi.org/10.1590/1983-40632016v4746560

Kerbauy, G.B. 2013. Fisiologia vegetal. 2 ed. Guanabara Koogan, Rio de Janeiro.

Lenton, J.R., Appleford, N.E.J., Croker, S.J. 1994. Gibberellins and $\alpha$-amilase gene expression in germinating wheat grain. Plant Growth Regulations, 15 (3), 261-270. DOI: https://doi.org/10.1007/BF00029899

Maguire, J.D. 1962. Speed of germination-aid in selection and evaluation for seedling emergence and vigor. Crop $\begin{array}{llll}\text { science, } & 2(2), & 176-177 . & \text { DOI: }\end{array}$ https://doi.org/10.2135/cropsci1962.0011183X000200020033x

Matos, A.H.P., Silva, A.G., Binotti, F.F.S., Costa, E., Binotti, E.D.C. 2020. Chemical agents in the production of high quality seedlings of Schizolobium amazonicum. Research, Society and Development, 9(8): 1-16. DOI: https://doi.org/10.33448/rsd-v9i8.6403

Marcos Filho, J. 2015. Fisiologia de sementes de plantas cultivadas. FEALQ, Piracicaba.

Melo, A.P.C., Seleguini, A., Veloso, V.R.S. 2014. Peliculização de sementes de tomate associada ao paclobutrazol. Bragantia, 73(2), 123-129. DOI: https://doi.org/10.1590/brag.2014.026

Nakagawa, J. Testes de vigor baseados na avaliação das plântulas. In: Krzyzanowski, F.C.; Vieira, R.D; França Neto, J.B. 1999. Vigor de sementes: conceitos e testes. ABRATES, Londrina.

Pacentchuk, F.; Sandini, I.E.; Rodrigues, J.D. Ono, E.O. 2018. Produtos à base de triazol como redutores de crescimento da cultura da soja. Revista de Ciências Agrárias, 41(2), 101-110. DOI: https://doi.org/10.19084/RCA16064

Parladore, N., Silva, A.G., Costa, E., Binotti, F.F.S., Silva, L.A., Vieira, G.H.C., Oliveira, A.F.G. 2019. Substrate volumes and application of paclobutrazol for ornamental pepper production.
Revista de Agricultura Neotropical, 6(3), 1-5. DOI: https://doi.org/10.32404/rean.v6i3.3342

Salles, J.S., Lima, A.H.F., Binotti, F. F. S., Costa, E., Binotti, E.D.C., Salles, J.S., Vieira, G.H.C., Souza, A.F.G.O. 2019. Calcium Nitrate Priming Increases the Germination Rate of Eggplant Seeds. Journal of Agricultural Science, 11(15): 181186. DOI: https://doi.org/10.5539/jas.v11n15p181

Sanz, L., Albertos, P., Mateos, I., Sánchez-Vicente, I., Lechón, T., Fernández-Marcos, M., Lorenzo, O. 2015. Nitric oxide (NO) and phytormones crosstalk during early plant development. Journal of experimental botany, 66(10), 28572868. DOI: https://doi.org/10.1093/jxb/erv213

Silva, A.G., Binotti, F.F.S., Costa, E., Pereira, T.C.C., Pinto, A.H. 2017. Sais liberadores de óxido nítrico na emergência e crescimento de seringueira. Enciclopédia Biosfera, 14(25):135142. DOI: https://doi.org/10.18677/EnciBio_2017A94

Silva, A.G., Costa, E., Pereira, T.C.C., Binotti, F.F.S., Scaloppi Junior, E.J., Zoz, T. 2020. Quality of rubber tree rootstock seedlings grown in protected environments and alternative substrates. Acta Scientiarum. Agronomy, 42(1), 110. DOI: http://doi.org/10.4025/actasciagron.v42i1.43469

Silva, C.B., Barbosa, R.M., Vieira, R.D. 2017. Accelerated aging as vigor test for sunn hemp seeds. Ciência Rural, 47(1): 1-6. DOI: http://doi.org/10.1590/0103-8478cr20151527

Silva, C.B; Marcos-Filho, J. 2020. Storage performance of primed bell pepper seeds with 24-Epibrassinolide. Agronomy Journal, 112 (2) p.1-13. DOI: https://doi.org/10.1002/agj2.20106

Simões, A.C., Alves, G.K.E.B., Ferreira, R.L.F. Araújo Neto, S.E. 2015. Qualidade da muda e produtividade de alface orgânica com condicionadores de substrato. Horticultura brasileira. $33(4), \quad 521-526 . \quad$ DOI: https://doi.org/10.1590/S0102-053620150000400019

Vieira, R.D., Krzyzanowski, F.C. 1999. Teste de condutividade elétrica. In: Krzyzanowski, F.C.; Vieira, R.D., França Neto, J.B. (Ed.) Vigor de sementes: conceitos e testes. ABRATES, Londrina, p.1-24.

Wanderley, C.S., Faria, R.T., Rezende, R. 2014. Crescimento de girassol como flor em vaso em função de doses de paclobutrazol. Ceres, 61(1), 35-41. DOI: https://dx.doi.org/10.1590/S0034-737X2014000100005 